\title{
Using a Genre-based Approach to Teach Mainland China College Students Writing
}

\author{
A Case Study
}

\author{
Shaofan Wang \\ School of Foreign Languages \\ North China Electric Power University \\ Baoding, China 071000
}

\begin{abstract}
The paper offers an optional approach to teach non-English major university students of mainland China how to write. It attempts to reveal the major problems in co college English writing: over-emphasis on linguistic accuracy, lack of systematic input of genre knowledge, and over-looking the development of students' writing ability. Based on the analysis of these problems, a case study was implemented to demonstrate the modification and significance to apply the genre-based approach to the college English course of mainland China.
\end{abstract}

Keywords—genre; genre-based approach; teach writing

\section{INTRODUCTION}

As discovery-oriented and ego-centered, process approaches contribute great respect for individual writers and for the process writing itself. There is little evidence that they can lead to the drastic improvement in writing in the second language contexts. The main reason is that the process approaches lack a well-formulated theory and systematic understanding of how the language works in human community and they think little of the elements outside the individual which are closely related with the context and help finish writing ultimately. Writing is not only to write. Instead, people want to achieve different purposes in different contexts by writing. So this must involve different ways in which the language is used, not universal rules (Halliday, 1994). Relatively, the process practitioners argue that teacher's involvement will weaken the students' intuitive understanding about language use and reduce their development of cognition on writing process. In process classroom, students are not given the explicit analysis on the structure of target text. Instead, students are expected to discover the appropriate form and acquire the knowledge from an unanalyzed sample by themselves through the process of writing. But in most cases because of lacking the knowledge of L 2 contexts, the second language learners are usually forced to use the conventions of their own cultures and produce a text that is contextually inappropriate.

"Genre is a stage goal oriented social process" (Martin, 1984). The concept of genre is based on the assumption that the features of the text in the social context can be described in a way which can be related to the texts like it. As writing is a

*The project item number 2014MS184 of the basic scientific research business expense of the Central University of North China Electric Power University. conscious behavior related to the social context and reflects certain social activities and meanings, genre-based pedagogies can help text producer link the language to the context, know how language varies and functions from one context to another and then read, understand, and perhaps relatively easily write specific text. Genre-based pedagogies require teachers to teach writing by explicit and systematic explanation of how language functions in social context. Such assumptions at least tell us how genre is taught.

But when these approaches are adopted in the non-Englishdominant countries, ESL teachers can hardly expect their students to have the appropriate cultural, social and linguistic background to write efficiently and effectively. They must assume that students' current literacy abilities differ from those needed in such contexts considerably. Teachers' explicit and effective instructions can bridge this gap. However, writing teachers have to make some adjustments for accommodating the local needs and constrains. So at this point, Chinese English teacher should ask themselves some questions-How is English writing being taught now? How to adapt our teaching under the influence of Western approach? What are the advantages and disadvantages for local adaption of such approach?

In China teaching writing even in universities often focus on the word and sentence level. And students' consciousness hardly gets the level of the whole contexts. Under the guideline of uniform syllabus and exam systems, university students' proficiency in English is exclusively evaluated by their scores on the CET (College English Test). In order to increase the pass rate of CET, some universities even implement the policy that the students cannot get the graduation certificates if not passing CET. Under such high pressure university teachers are concerned about teaching students of correct forms and testtaking skills rather than develop their thoughts in writing. In most universities of mainland China, there is no specialized class established for writing for non-English major students while they have intensive-reading class and listening class. In many teachers' and students' eyes, writing is a process which mainly depends on the learners themselves and teaching cannot help too much. Teachers' task in writing is only leaving an assignment to students, collecting the essays, correcting the wrong spellings and grammatical use, more like error 
correction exercise, and then distributing essays to the students again. What teachers often say is students with low proficiency in writing should try to memorize model writings as many as possible. A student even told me when preparing for CET he memorized thirty pieces of model writings. But once the exam was over, he could only recall a little about the content of model writings. And he did not think such memory could help him much in the future. From this case, we can find that students learn writing only by rote or too mechanically. They cannot understand the social purpose of writing and how important and useful the writing it is for their English study and for their future. But as globalization develops, students who have a good command of English will be more competitive than their peers in terms of career choices or personal improvement. This research is an attempt to challenge the traditional way of teaching writing and to investigate whether the genre-based writing can be adopted in mainland China.

\section{LITERATURE REVIEW}

Today, genre is one of the most important and influential concept in language teaching. Johns (2002) advocates it as "a major paradigm shift" in language studies and teaching. Hyland (2003) thinks genre-based approach is a way to "exposing students to a variety of texts within the relevant target genre and providing them with an understanding of how the contexts and purpose of these texts are related to their structure and lexicogrammar". But genre theory attempts to find out a more balanced approach to teaching writing rather than replace the process wiring (Kim and Kim, 2005).

\section{RESEARCH METHOdOLOGY}

The research approach of this study can be described as a qualitative case study. The research was implemented in a college English course, a compulsory course for non-English major students who are freshmen or sophomores in North China Electric Power University, in the north of China.

Students, from the Accounting and Automation Departments, have little touch with English in their daily life. So their English are mainly learned in classroom. There are 55 students and none of them has ever been taught by the genrebased approach.

My colleague Jane and I designed a teaching unit with focusing on the genre of discussion and drawing on the four stages of teaching-learning cycle half a year ago before CET-4. The class was conducted by Jane. She got the MAELT in 2005 and has been devoting the study of the genre-based approach. The whole class was video-recorded. After the class, we interviewed the students involved in the research for getting a feedback to the genre-based approach. The students' essays in the independent construction stage were collected for our further analysis. Only one class cannot reflect the substantial influence of genre-based approach on writing. But it helps us to consider whether it is time we brought modification to the traditional Chinese writing approach or not.

\section{THE DisCUSSION GENRE}

According to the syllable, college English teaching aims at cultivating in students a relatively high ability in reading, listening, speaking, writing, and translation, so that they will be able to employ English as a means for exchanging information and college English teacher should help students to build up the solid knowledge base, develop the relatively high language literacy skills, and enhance their second language cultural knowledge in order to meet the needs of social and economic progress (College English Syllabus Revision Team,1999). With the respect of writing, to meet the basic requirements, a college student are able to write a short essay of 120 to 150 words within half an hour when given a certain topic or outline (College English Syllabus Revision Team, 1999) (currently popular in China such as banning the use of disposable plastic bags, building the green campus and other similar topics) with no.

* The names of students used in this case study are aliases significant language mistakes (College English Syllabus Revision Team, 1999).

Analyzing the writing testing models on CET-4 of recent years, there usually exits a relatively fixed structure in college writing. As follows:

Paragraph 1: Introduction

Paragraph 2: Its advantages

Paragraph 3: Its disadvantages

Paragraph 4: Conclusion

According to the above chart, the college writing focuses on the genre of discussion. Based on the work of Coffin, Donohue and North (2009), the generalized generic structure of the discussion genre is:

Issue $\wedge$ Arguments for $\mathrm{N} \wedge$ Arguments against $\mathrm{N} \wedge$ (Position)

In this structure, 'issue' is the part of the text in which the writer raises an issue or a social phenomenon. 'Argument for/against' is concerned with the different views people hold. The symbol ' $\wedge$ ' indicates that the element to the left of the symbol should precede that to its right. The sign ' $\mathrm{N}$ ' means that this part of the text can be repeated. Finally ' position' involves the writer's own standpoint on the issue discussed above ( Kongpetch, 2006).

In order to write the discussion effectively, students need also to have a command of language features peculiar to the genre. The dominant language features of written discussion include the use of.

Present Tense is used to demonstrate the speaker's attitude at the time of speaking (Thompson, 1996).However, other tenses can also be used where the timing of text changes. For example, if the writer recalls the past events, the past tense will be appropriate.

Declarative mood signals that it is the expression of belief (a claim, a report) that the state of the world expressed by the propositional content is true (Arundale,1999). 
Modality the way we meanings are made to construct probability/frequency and obligation/inclination (Thompson, 1996).

Generic nominal groups allow the writer to package complex events or entities as single things so they can be thematized and discussed (Hyland, 2004).
My study focuses on combining the generic structure and some grammatical features of the discussion genre to apply them to the analysis of how using the genre-based approach affects the students' writing. The teaching unit will be discussed below. "Fig. 1"

\begin{tabular}{|c|c|c|c|}
\hline Genre & Social purpose & Generic stages & Lexicogrammatical features \\
\hline personal recount & $\begin{array}{l}\text { to retell a sequence } \\
\text { of events in the } \\
\text { narrator's life }\end{array}$ & $\begin{array}{l}\text { - orientation } \\
\text { - record of events } \\
\text {-(reorientation) }\end{array}$ & $\begin{array}{l}\text { past tense, temporal adjuncts, declarative mood, } \\
\text { personal pronoun }\end{array}$ \\
\hline $\begin{array}{l}\text { biographical } \\
\text { recount }\end{array}$ & $\begin{array}{l}\text { to retell the events } \\
\text { of a person's life }\end{array}$ & $\begin{array}{l}\text { - orientation } \\
\text { - record of event } \\
\text { - (evaluation of person })\end{array}$ & $\begin{array}{l}\text { - past tense (present tense can be used for effect), } \\
\text { temporal adjuncts, declarative mood, third person } \\
\text { pronoun he/she }\end{array}$ \\
\hline narrative & to tell a story & $\begin{array}{l}\text { - orientation } \\
\text { - complication } \\
\text { - evaluation } \\
\text { - resolution }\end{array}$ & $\begin{array}{l}\text { - past tense (present and past may occur in dialogue), } \\
\text { temporal adjuncts, declarative mood (other mood } \\
\text { choices may occur, particularly in dialogue), third person } \\
\text { pronoun he/she, they, evaluative lexis }\end{array}$ \\
\hline taxonomic report & $\begin{array}{l}\text { to classify and } \\
\text { describe } \\
\text { phenomenon }\end{array}$ & $\begin{array}{l}\text { - identification of phenomenon } \\
\text { and classification } \\
\text { - description of types or parts } \\
(1-n)\end{array}$ & $\begin{array}{l}\text { - present tense, declarative mood, generic nominal } \\
\text { groups, third person pronoun it, they }\end{array}$ \\
\hline procedure & to give instructions & $\begin{array}{l}\text { - goal } \\
\text { - material } \\
\text { - steps (1-n) }\end{array}$ & - present tense, adjuncts of place, imperative mood \\
\hline explanation & $\begin{array}{l}\text { to explain how } \\
\text { something works }\end{array}$ & $\begin{array}{l}\text { - identification of phenomenon } \\
\text { - explanation equence }\end{array}$ & $\begin{array}{l}\text { - present tense, declarative mood generic nominal } \\
\text { groups, causal and temporal connectors }\end{array}$ \\
\hline discussion & $\begin{array}{l}\text { to consider different } \\
\text { perspectives on an } \\
\text { issue }\end{array}$ & $\begin{array}{l}\text { - issue } \\
\text { - arguments for } \\
\text { - arguments against } \\
\text { - (position) }\end{array}$ & $\begin{array}{l}\text { - present tense (and past where appropriate), } \\
\text { declarative mood (some use of interrogatives in spoken } \\
\text { mode), modality, generic nominal groups }\end{array}$ \\
\hline legal judgement & & $\begin{array}{l}\text { - facts as found } \\
\text { - relevant law } \\
\text { - decision/ruling }\end{array}$ & $\begin{array}{l}\text { - present tense, third person pronouns declarative mood } \\
\text { - use of conditional clause, epistemic (may) and deontic } \\
\text { (shall) modality }\end{array}$ \\
\hline
\end{tabular}

Source: Coffin et al 2009:260

Fig. 1. Genres and generic stages

\section{THE Discussion TEACHING UNIT}

The designed discussion teaching unit was in accordance with the 4 stages of the teaching-learning cycle. "Fig. 2"

Stage 1 Building up the field knowledge- revealing genre purposes and the context in which a genre is commonly used (Hyland, 2004). We chose the topic "Should parents send their kids to art classes". The students were little exposed to English in their daily life. In English teaching, it is necessary to connect English with their daily life. We thought "art class" might be an interesting topic for students because in recent years some educationalists have been advocating to release the ex-curriculum pressure on the students. Some students in the class even had the same experience. To enable the students to get the relevant information as well as to practice their language skills, some activities are designed including: brainstorming, reading journalistic materials and presentations.

Stage 2 Modeling of the text-analyzing the genre to reveal its generic structure and grammatical features ( Hyland, 2004). This stage needs teachers' explicit explanation of the generic structure and grammatical features of discussion so that students become aware of how it functions to achieve its purpose.

Students were asked to analyze the generic structure of model text 1 (see Appendix 1) by answering the following questions:

1) Questions concerning the context of the text.

What is the text about?

What purpose does it serve?

Who produced the text, and who for?

What social activity does the genre normally occur in?

What does the channel tell us about the text? 




Source: Martin 1999:131

Fig. 2. Teaching-learning cycle

2) Questions about the overall organization of the model text to find out what the writer did in order to present a discussion and how he/she organized each paragraph.

What did the writer do first, next and last?

What does the first sentence of every paragraph give information about?

To reinforce the students' understanding, Jane worked with them to draw a structure outline on the whiteboard, summarizing the generic structure of the discussion should consist of 'issue', 'argument for', 'argument against', and 'position'.

Explanations on grammatical features focused on the four features of the discussion genre, namely present tense, declarative mood, modality, and generic nominal group. Jane first explained the definitions of four grammatical features to the students and provided them with the examples. Then she asked the students to reread the model text to find out each feature and discuss in a small group.

Stage 3 Joint construction of text- teacher-support practice in the genre (Hyland, 2004). To check the students' understanding and command of the discussion genre, Jane asked the students to make a group presentation on the topic "Golden Week". The presentation must draw on the knowledge the students had acquired about the generic structure and grammatical features of the discussion genre from the previous stages. Hyland (2004) thinks at this stage teacher and learner should collaborate to construct whole examples of the genre with the teacher gradually reducing his or her contribution and learner gaining greater control over the writing. So the teacher acts as a facilitator for sharing writing activities and as a responder to student writing. So in this stage, Jane transferred from a conductor to a participant with walking around the classroom, observing and participating the students' discussion.

Stage 4 Independent construction of text-writing is a must for learning writing (Hyland, 2004). The independent writing is the ultimate goal for the genre-bases writing. To demonstrate their understanding of the discussion genre the students were expected to combine the knowledge they have learned to produce an independent writing. We asked the students, independently, to write an essay of approximately 120-150 words on the topic "Should parents send their kids to art classes?" outside the classroom. The teachers' feedback focused on the generic structure and grammatical features of the discussion genre after collecting the essays. In this stage, the teachers acte as advisors.

Data collection and analysis

TABLE I. SUMMARY OF THE COLLECTED DATA

\begin{tabular}{|l|l|}
\hline \multicolumn{1}{|c|}{ Data } & \multicolumn{1}{|c|}{ Quantity } \\
\hline $\begin{array}{l}\text { Photocopies of students written texts on } \\
\text { the discussion }\end{array}$ & 55 copies \\
\hline $\begin{array}{l}\text { Video-recording of the interview } \\
\text { between the teacher and students outside } \\
\text { the classroom }\end{array}$ & About two hour \\
\hline
\end{tabular}

The reasons that the above data are collected are discussed as follows.

- Photocopies of students written texts on the discussion: Writing is the ultimate goal of the genre-based writing. So the students' essays can clearly reflect the students' understanding about the genre and its social context.

- Video-recording of the interview between the teacher and students outside the classroom: After the class, an interview between the teacher and the students was held to obtain the students' opinions and attitude towards the genre-based approach. The students are required to answer honestly the following questions.

Which aspects in the teaching-learning cycle do you consider most/least helpful for your writing? Why?

Do the genre-based writing help you to learn to write? How?

The analysis of the above data is classified into linguistic and content analysis. The collection of the essays is classified linguistic analysis and the video of the interview is classified as content analysis.

Students' reaction toward the genre-based approach

In order to investigate whether the genre-based approach can be modified to suit the Chinese L2 writing, the students' attitude must be taken into account. The data can reflect the student's positive attitude towards the genre-based approach. Most of them think the genre-based approach not only enable them to know why/how to write but also to write better. The students' reaction to the every section is summarized in the following table.

TABLE II. STUdENTS' POSITIVE REACTION TO THE TEACHINGLEARNING CYCLE

\begin{tabular}{|l|l|}
\hline \multicolumn{1}{|c|}{ Stages } & \multicolumn{1}{|c|}{$\begin{array}{c}\text { Numbers of } \\
\text { students }\end{array}$} \\
\hline Building up the field knowledge & 30 of 55 \\
\hline Modeling the text & 50 of 55 \\
\hline Joint-construction & 9 of 55 \\
\hline Independent construction & 55 of 55 \\
\hline
\end{tabular}


a) Building up the field knowledge: As indicated from the above table, 30 students responded positively towards this stage. Most of them think this section wastes too much time because the arguments for the issue are easy to see.

I think the issue is the hot topic in the society but usually will not bring too much controversy. The arguments are obvious. So teachers needn't to design a lot of pre-reading activities. Our problem is how to write organizationally. (Janet*,23/04/2010)

The students' criticism reflects that they can't understand the purpose of this stage is to provide students with enough information and vocabulary before their writing. But the positive influence of this stage can be seen from the students' essays. Most students drew on the information especially the vocabulary provided in this stage.

b) Modeling of text: This section gained the students' overwhelming support. It is not difficult to understand this section was attractive to students because it enables them to know how to write.

I like this part because through the teacher's detailed explanation I know how to write such genre in a logical way. I hope such courses can be continued because such courses are really helpful for us to solve the structural problem in writing. (Mike,23/04/2010)

c) Joint-construction: This section is thought to be the most useless section.

I think it's boring. Some people don't want to share their ideas at all. We are in the embarrassing silence. (Julie,23/04/2010)

I think we can delete this part. Some classmates are too lazy to do nothing at all. Team work only wastes time.(Apple,23/04/2010)

The students' negative responses remind us that teachers should be more active to participate this section to guide and supervise the students' activities because immersed into the traditional education model, many students have formed the "spoon-fed" habit.

d) Independent construction: All the students found this stage to be valuable because it met their expectation of writing course. This stage offers them an opportunity to assess their control of the genre. Practice makes perfect. This part lets me know how well I have understood the genre and how well I can write the relevant essay. (Bob,23/04/2010)

To summarize, the students thought the genre-based approach was worthwhile. It can help them to write the essay approximate to the model of the text and to the English convention. In order to demonstrate the students' understanding and command of the discussion genre, one of the students' essays can be seen in Appendix 2.But the students' criticism also suggests that we should modify the genre-based approach to the Chinese education system.

Implementations for applying genre-based approach to writing course of mainland China
While it is difficult to generalize from one case study to conclude genre-based writing is better than process writing. But we cannot ignore the influence the genre-based approach brought on the students. If genre-based approach is used as an effective approach to teach writing in China, some modification must be implemented.

- Choices of topics and genres: According to Krashen (1981), the input has to be at $\mathrm{i}+1$ level. The data suggest us when designing the curriculum content for teaching Chinese students English, teachers should choose the topics which can improve the students' interest and are relevant to their daily life as well as have some depth and are a bit more challenging which engage students to develop their knowledge.

- Transfer of the role: Based on the analysis of data, genre-based approaches require teacher to transfer the conductor in the classroom to the combination of conductor, participant, facilitator and responder. Genre-based approach also needs students to be more active and collaborative in their learning. Both requirements change the teachers' and students' traditional perception on writing. So we should give them more time and space to accept this transfer.

\section{CONCLUSION}

This research reveals that genre-based approach is valuable for the writing course of mainland China. Through the teachers' explicit explanation on the genre, students can combine the knowledge of word, sentence, grammatical feature and context to produce a successful essay approximate to the English conventions. Genre-bases approach is explicit, systematic, needed-based, supportive, empowering, critical and consciousness raising (Hyland, 2004). It is worthwhile to implement this approach in others contexts and other universities across mainland China.

\section{REFERENCES}

[1] Coffin, C. Donohue, J. \& North, S. (2009). Exploring English grammar: from formal to functional. London: Routledge

[2] College English Syllabus Revision Team. (1999). Daxue yingyu jiaoxue dagang (Xiuding ben) [ College English syllabus (Rev. ed.)]. Beijing: Gaodeng Jiaoyu Chubanshe [ Higher Education Press]

[3] Halliday, M.A.K (1994). An introduction to functional grammar (2nd Ed). London: Edward Arnold

[4] Hyland, K. (2003). Genre-based pedagogies: A social response to process. Journal of Second Language Writing, 12, 21

[5] Hyland, K. (2003). Second language writing. Cambridge: Cambridge University Press

[6] Hyland, K. Belcher, D. \& Jun, L. (2004). Genre and second language write.

[7] Ann Arbor: The University of Michigan Press

[8] Johns, A.M. \& Kroll, B. (2002). Genre and ESL/EFL composition instruction. Exploring the dynamics of second language writing. New York: Cambridge University Press

[9] Kim, Y. \& Kim, K. (2005). Teaching Korean university writing class: Balancing the process and the genre approach. Asian EFL Journal Online, 7(2), 60-90.

[10] Kongpetch, S (2006). Using a genre-based approach to teach writing to Thai student: A case study. Prospect Vol.21, 2, 3-33 
[11] Krashen, S.D. (1981). Second language acquisition and second language learning

[12] Martin, J.R. \& Christie, F. (1984). Children writing: reader. Australia: Deakin University Press

[13] Martin, J.R. \& Christie, F. (1999). Pedagogy and the Shaping of consciousness. London: Continuum

[14] Thompson, G. (1996). Introducing functional grammar. London: Arnold. 